\title{
動圧軸受を応用した長期使用血液ポンプの研究開発 Development of blood pumps with hydrodynamic bearings
}

\author{
○正 築谷朋典（国循） \\ 非＼cjkstart妙中義之（国循） \\ 非＼cjkstart巽＼cjkstart英介（国循）
}

Tomonori TSUKIYA, National Cerebral \& Cardiovascular Center, Fujishirodai 5-7-1, Suita, Osaka 565-8565

\begin{abstract}
Rotary blood pumps consisting of hydrodynamic bearings have been developed to realize a long-term mechanical circulatory/respiratory support system. An axial flow pump was developed for an implantable left ventricular assist device, designed to work for at least five years without maintenance. An extracorporeal centrifugal pump was developed for cardiopulmonary support system, designed to work for as long as one month. Both systems demonstrated sufficient hydrodynamic performances and biocompatibility in the chronic animal experiments. The mechanical destruction of blood cells due to high rotation of the impellers were within an acceptable range.
\end{abstract}

Key Words: Pumps, Impellers, Blood, Hydrodynamic Bearing

\section{1. 緒言}

心不全治療における非薬物療法の一つとして、血液ポンプ を用いた機械的補助循環が広く用いられるようになった。血 液ポンプを中心とする機器の性能が飛躍的に向上し、耐久性、 信頼性が著しく向上したことが最大の理由であろう。血液ポ ンプの研究開発自体は、心臓血管外科の黎明期でもある 1950 年代後半にまで遡り、当時は心臓を切除して左心・右心の 2 つの血液ポンプで代行する完全人工心臓(Total Artificial Heart：TAH)の開発が目的であったが、その後、心藏のポン プ機能を補助・代替する補助人工心臓(Ventricular Assist Device : VAD)の開発が中心となっていった。これらのデバイ スは心臓移植までのつなぎとして使用される前提で開発さ れてきたが、数年間メンテナンスフリーで使用できる耐久性 が必要である。装置内で血液が凝固し血栓を形成しない性能

（抗血栓性）はそのうちでも最も重要な性質であり、血液接 触面の材料・機構のデザインによって多くの検討がなされて きた。小型化が容易な連続流ポンプは、軸シール部における 摩擦熱や軸付近の㮰滞を取り除くという大きな課題を抱え ていた。非接触軸受を有する血液ポンプの実現により優れた 耐久性を持つ血液ポンプが実用化され始めた ${ }^{(1)}$ 。

我々は、高い耐久性を有する血液ポンプを中心とする治療技 術の拡充を目指して臨床ニーズに応じた様々な形態の血液 ポンプの開発を行ってきた。ここでは、非接触で羽根車を支 持する動圧軸受を有する 2 つの血液ポンプ開発の成果につ いて述べる。

\section{2. 体内埋込型補助人工心臓用軸流ポンプ}

体内埋込型補助人工心臓は、主に左心室のポンプ機能を補 助するために左心室から血液を吸い込み、ポンプによって昇 圧後大動脈に吐き出寸形式をとる。血液ポンプは胸腔あるい は腹壁内に留置し、ポンプ駆動用ケーブルが皮膚を貫通して 体外のコントローラに接続される（図 1)。

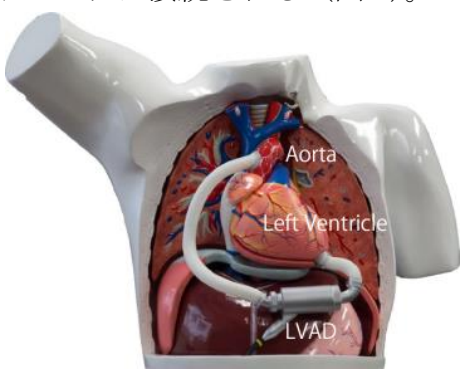

米国では、軸流型の血液ポンプ（Heartmate2, Thoratec）が従 来の拍動型ポンプに比べ、小型化、耐久性の向上、感染率の 低下等多くの面で優れていることが実証され、現在では年間 3000 例以上使用されている(2)。このポンプのインペラには永 久磁石が埋め込まれ、DC ブラシレスモータの回転子を兼ね ているが、両端をピボットで支持しているために機械的接触 が残り、このピボット部での血栓形成例も報告されている(3) 我々は、非接触軸受によって高い抗血栓性を持つポンプの実 現を目的として、動圧軸受型軸流ポンプの開発を行った。開 発した軸流ポンプは、全ての血液接触面がチタン合金製であ り、長さ $75 \mathrm{~mm}$ 、直径 $29 \mathrm{~mm}$ である。ポンプ本体の重量は $150 \mathrm{~g}$ である。インペラには永久磁石が内包され、外周部に設置さ れたコイルにより駆動される。インペラは円筒状のボディに 羽根を有しており、図 2 に示すように、中心を貫通する軸と の隙間において動圧軸受を構成している。補助人工心臓は患 者の状態に応じて補助すべき流量ならびに発生する圧力が 異なるが、平均的な動作点として流量 $5.0 \mathrm{~L} / \mathrm{min}$ 、揚程 100 $\mathrm{mmHg}$ が用いられており、本ポンプは約 $9000 \mathrm{rpm}$ において この条件を達成可能である。この時のモータ消費電力は約 5 W であるため、モータを含めたエネルギ効率は約 $22 \%$ \% る。ポンプの圧力特性を図3に示す。軸流ポンプではあるが、 右上がり不安定の点は存在していない。抗血栓性、血球破壊 量を含む生体適合性に関しては、実験動物を用いて模擬的に 実使用条件で3か月間連続運転によって評価を実施しており、 合計 8 例の 3 か月運転では十分な抗血栓性と臨床的に許容で きる範囲の血球破壊量であることを確認している。運転中は 生体心の拍動により流量が 2-7 L/min の範囲で変動したが、 インペラが接触した形跡は見られず、補助人工心臓としての 駆動条件においても動圧軸受は安定して動作していた。
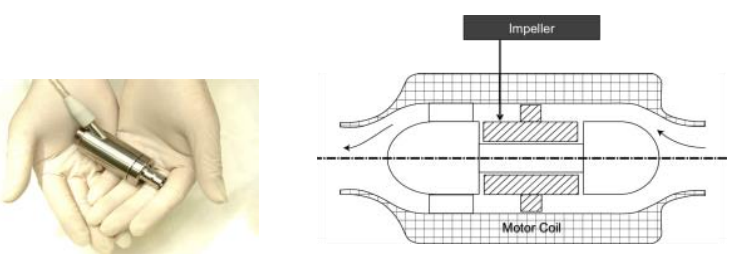

Fig.2 Structure of the axial flow pump

Fig.1 Implantable left ventricular assist device 


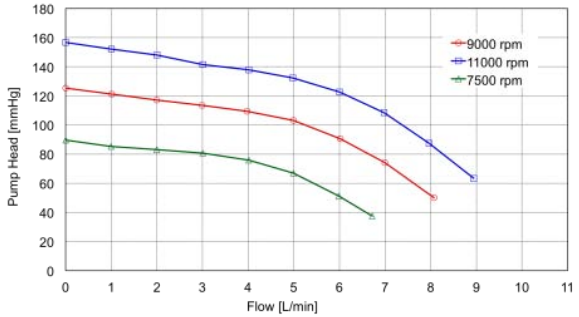

Fig.3 Hydrodynamic Characteristics of the axial flow pump

\section{3. 体外設置型呼吸循環補助用遠心ポンプ}

血液ポンプを用いた循環補助法のうち、緊急に循環補助を 必要とする患者には、救命と血行動態の安定を図る目的で血 液ポンプと人工肺を組み合わせた心肺補助装置の使用が検 討される(4)。このような目的に使用する血液ポンプには現在 専用機種はなく、開心術で用いられる体外循環を想定した 6 時間までの機種が、必要であればポンプを交換しつつ使用さ れている。しかしながら、ポンプ交換の際には補助を一時的 に中断し強力な抗凝固療法を多用するといったリスクに加 え、複数のポンプを使用することで患者・病院にとっても経 済的負担が大きいという問題が存在する。抗血栓性に優れ、 数日から一か月程度まで連続使用可能な血液ポンプが実現 できれば、血液ポンプと人工肺の組み合わせにより呼吸循環 補助を行う Extracorporeal Membrane Oxygenation : ECMO ${ }^{(5)}$ と 呼ばれる補助法や、心原性ショック等の急性心不全患者に対 する循環補助法に用いることが可能である。血液ポンプの抗 血栓性が優れていれば抗凝固療法を最小化することが可能 となり、出血や炎症反応といった合併症を抑制する効果が期 待できる。

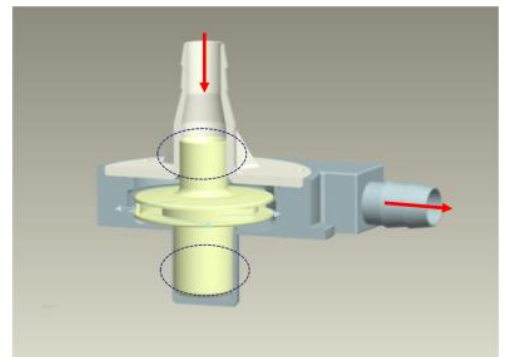

Fig.4 Cross section of the centrifugal pump

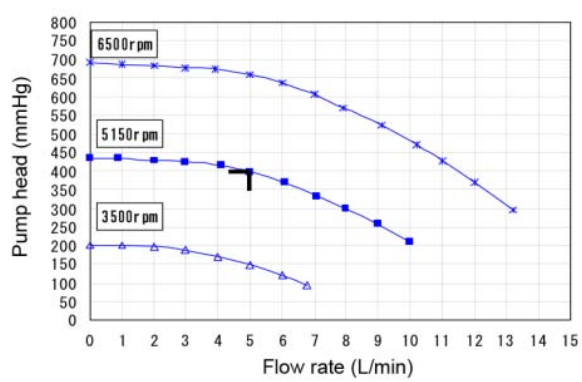

Fig.5 Hydrodynamic Characteristics of the centrifugal pump

我々が開発を行った遠心ポンプは、図 4 に示すように、駆動 用永久磁石内包部とインペラ入口部の 2 か所で軸方向の動圧 軸受を構成する新しい形状のインペラを有する。このインペ ラはディスポーザブルでありながら動圧軸受により非接触 で回転可能である。開発したポンプはポリカーボネート製の ポンプヘッドと駆動モータから構成され、モータ側に設置さ れた永久磁石とインペラ内部の永久磁石による時期カップ リングによって駆動される。モータを含めた寸法は長さ 123 $\mathrm{mm}$ 、直径 $60 \mathrm{~mm}$ であり、重量は $600 \mathrm{~g}$ である。ポンプヘッ ドの充填体積は $18 \mathrm{~mL}$ であり、体外設置型の遠心ポンプとし
ては現時点で最も小さい。心肺補助装置用血液ポンプの動作 点は回路構成に大きく依存するが、ここでは比較的高い揚程 にも対応できるよう、流量 $5.0 \mathrm{~L} / \mathrm{min}$ 、揚程 $400 \mathrm{mmHg}$ を動 作点として設計しており、約 $5000 \mathrm{rpm}$ でこの条件を満たす。 図 5 に遠心ポンプのポンプ特性を示す。インペラはシュラウ ドを持つ完全二次元羽根である。磁石部を内包している部分 には中心に孔が設けられており、インペラを出た血液の一部 がポンプ底部を洗い流し、血栓を防止する効果を狙っている。 この遠心ポンプについても、動物実験によって生体適合性の 検討を行っており、人工肺と組み合わせた呼吸循環補助シス テムとして、連続 30 日間の運転を安定して行うことに成功 しており、ポンプの安定した動作、優れた抗血栓性を実証す ることに成功した。また、動圧軸受を構成する狭い隙間での 血球破壊についても許容範囲内であった。

このポンプは人工肺を使用しない簡易左心バイパス用ポン プとしても有用であると考えられるが、左心バイパスに用い る際は回路が短く揚程が低くなるためにより低い回転数で の運転となる。そのために動圧軸受の安定性に関して注意が 必要であると考えられる。これまでの検討で揚程 $100 \mathrm{mmHg}$ 程度の運転条件でも安定した動圧浮上の状態が実現できて おり、このとき血球破壊量も問題ないことが実験的に確かめ られている。現在、1 ケ月運転の耐久性・安全性を動物実験 で確認中である。

\section{4. 結語}

非接触軸受である動圧軸受は、抗血栓性に優れた血液ポン プを実現するための重要な要素である。著者等は近年著しい 発展を遂げてきた機械的補助循環法による治療技術のさら なる拡充を目指し、本研究で行ったような動圧軸受を応用し た血液ポンプならびにそのシステムを開発している。血液ポ ンプの大きな特徵として、動作点があらかじめ決定できず幅 広い流量と回転数の下で運転する可能性があるため、動圧軸 受が接触せず安定に動作する条件について十分検討してお く必要がある。また、動圧軸受を構成する狭い流路は高いせ ん断応力による血球破壊の可能性があることに留意すべき であると考える。

\section{引用文献}

(1) Kormos RL, Miller LW, Mechanical Circulatory Support : A Companion to Braunwald's Heart Disease, Elsevier, 2012.

(2) Kirklin JK, et al., Fifth INTERMACS annual report: Risk factor analysis from more than 6,000 mechanical circulatory support patients, Journal of Heart and Lung Transplantation, 32, 141-156, 2013.

(3) Meyer AL, et al., Thrombus formation in a HeartMate II left ventricular assist device, Journal of Thoracic and Cardiovascular Surgery, Vol.135, No.1, pp.203-204, 2008.

(4) Extracorporeal Life Support Organization, General Guidelines for all ECLS Cases, 2009.

(5) Sinard JM, Bartlett RH, Extracorporeal membrane oxygenation (ECMO): prolonged bedside cardiopulmonary bypass, Perfusion, Vol.5, pp.239-249, 1990. 